\title{
Review Article \\ Perspectives of Biogas Conversion into Bio-CNG for Automobile Fuel in Bangladesh
}

\author{
M. S. Shah, ${ }^{1}$ P. K. Halder, ${ }^{2,3}$ A. S. M. Shamsuzzaman, ${ }^{2}$ M. S. Hossain, ${ }^{1}$ \\ S. K. Pal, ${ }^{1}$ and E. Sarker ${ }^{4}$ \\ ${ }^{1}$ Department of Petroleum and Mining Engineering, Jessore University of Science and Technology, Jessore 7408, Bangladesh \\ ${ }^{2}$ Department of Industrial and Production Engineering, Jessore University of Science and Technology, Jessore 7408, Bangladesh \\ ${ }^{3}$ School of Engineering, Royal Melbourne Institute of Technology University, Melbourne, VIC 3001, Australia \\ ${ }^{4}$ Hajee Mohammad Danesh Science and Technology University, Dinajpur 5200, Bangladesh
}

Correspondence should be addressed to P. K. Halder; pobitra.halder@gmail.com

Received 17 March 2017; Revised 11 June 2017; Accepted 31 July 2017; Published 30 August 2017

Academic Editor: Pallav Purohit

Copyright (C) 2017 M. S. Shah et al. This is an open access article distributed under the Creative Commons Attribution License, which permits unrestricted use, distribution, and reproduction in any medium, provided the original work is properly cited.

\begin{abstract}
The need for liquid and gaseous fuel for transportation application is growing very fast. This high consumption trend causes swift exhaustion of fossil fuel reserve as well as severe environment pollution. Biogas can be converted into various renewable automobile fuels such as bio-CNG, syngas, gasoline, and liquefied biogas. However, bio-CNG, a compressed biogas with high methane content, can be a promising candidate as vehicle fuel in replacement of conventional fuel to resolve this problem. This paper presents an overview of available liquid and gaseous fuel commonly used as transportation fuel in Bangladesh. The paper also illustrates the potential of bio-CNG conversion from biogas in Bangladesh. It is estimated that, in the fiscal year 2012-2013, the country had about 7.6775 billion $\mathrm{m}^{3}$ biogas potential equivalent to 5.088 billion $\mathrm{m}^{3}$ of bio-CNG. Bio-CNG is competitive to the conventional automobile fuels in terms of its properties, economy, and emission.
\end{abstract}

\section{Introduction}

Transportation system is the basement of the industrial and socioeconomic development of any country and predominantly depends on fossil fuel [1]. In the United States, about $28 \%$ of the total energy consumption is used for transportation system of which almost $86 \%$ comes from gasoline and diesel fuels [2]. Due to the rapid depletion and high cost of liquid fuel, natural gas is used in compressed form named compressed natural gas (CNG). Currently, it has become very popular alternative to liquid fuel for vehicles in the world due to its low price [3]. It is estimated that during 2013, approximately 18.09 million natural gas vehicles (NGV) have been run by CNG in the world. Nowadays some countries like the United States, Germany, Australia, Austria, India, and so forth already have been using bio-CNG as the vehicles fuel in place of CNG $[4,5]$.

In the United States, 8 renewable natural gas projects, namely, bio-CNG 50, bio-CNG 100, and bio-CNG 200, have been installed during 2011 to 2013 [5, 6]. These plants produce approximately 200 gallons of diesel equivalents (DGEs)/day, 399.77 DGEs/day, and 790 DGEs/day, respectively, which can be enough fuel for 25-30 vehicles, 5-8 trash trucks, or 40-50 passenger vehicles and 25 heavy duty vehicles or $40-50$ light duty vehicles per day. In India, first indigenous bio-CNG plant with capacity of 85 cubic meters has been made at Rajasthan with the help from IIT, Delhi. The plant uses cow dung as feed material and the production cost of $1 \mathrm{~kg}$ of bioCNG is about USD $0.23-0.24$ which is much cheaper than the petro-based CNG [7]. During the year 2013, in Austria about $7 \mathrm{GWh}$ energy equivalent vehicle fuel (biomethane) was produced from biogas and three filling stations were established at biogas upgrading plants. On the other hand, Germany produced almost $0.1 \%$ of total consumption of vehicle fuel from biogas in year 2012 equivalent to approximately 0.35 TWh of energy. At the end of 2012, about 120 biomethane feed plants were in operation with an installed capacity of $72,000 \mathrm{Nm}^{3} / \mathrm{h}$ in Germany that could be fueled for 0.1 million gas vehicles in 119 out of the 900 CNG filling stations [8]. Linköping, a city of Sweden is the promising 
model of bio-CNG integration into public transportation. The plant produces about 4.7 million $\mathrm{m}^{3}$ of upgraded biogas per year that is used in 64 buses and a number of heavy and light duty vehicles through 12 public refueling stations. Besides, this is the pioneer in using biomethane in train. This plant reduces approximately 9,000 tons of $\mathrm{CO} 2$-emissions from urban transport as well as sulphur and nitrogen oxides per year [9].

Bangladesh is an energy starved country where natural gas and petroleum products are the main sources of energy. However, the country has only 0.3 trillion cubic meters of proved natural gas reserve at the end of 2014 which will be exhausted within next 10-12 years if the existing consumption rate continues. In addition, the petroleum reserve in Bangladesh is only about $8 \%$ of the total demand; it has to import about 1.2 million tons of crude oil and 2.6 million tons of refined petroleum products each year [10]. The country consumed almost 23.6 billion cubic meters of natural gas and 5.7 million tons of oil in the year 2014 [11]. The transportation sector consumes approximately $46.46 \%$ of total petroleum consumption and $6 \%$ of total natural gas consumption. Up to October 2015, the country has about 560 CNG refueling stations and $180 \mathrm{CNG}$ conversion workshops which have converted approximately 245,372 vehicles into CNG vehicles. Currently, the country has total of 285,755 CNG run vehicles including imported vehicles. However, taking into account the future security of liquid and gaseous vehicle fuel, it is necessary to find out alternative renewable source for transport fuel immediately. Bio-CNG produced from the purification and then compression of biogas can be the most suitable alternative for traditional vehicle fuel in Bangladesh. Bangladesh has enormous amount feed material for biogas production which can be the most effective option for bioCNG. However, most of the biogas plants in the country are small-scale domestic digester producing biogas mainly for cooking and lighting. The main issues for commercial biogas implementation in Bangladesh are technological knowledge gap, uncertainty of feed materials, and financial insufficiency. Although the Government of Bangladesh is financing domestic biogas digester through some organization, it has no specific policy regarding the commercialization of bio-CNG production from biogas. The study assesses the scope and potentiality of bio-CNG production from biogas and its technology for automobile in Bangladesh.

\section{Present Status of Transportation Fuels in Bangladesh}

2.1. Petroleum Products. Petroleum products are the most usable liquid fuels which are derived from crude oil processing in oil refineries. The majority of crude oil is converted into petroleum products, which include several classes of fuels [12]. Petroleum fuel mainly contains kerosene, diesel, and petrol and is considered as the major sources of commercial energy in Bangladesh. The transportation sector is the primary consumer of petroleum fuels which accounts for about $46.46 \%$ of total consumption 5,321,423 tons as illustrated in Figure 1. In the fiscal year 2014-2015, transportation sector consumes approximately $2,472,486$ tons of petroleum oil

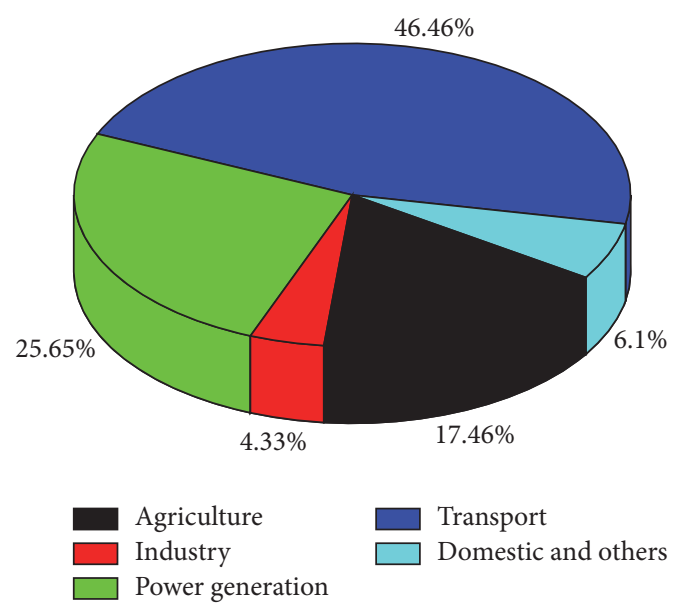

FIGURE 1: Sector-wise consumption of petroleum fuels in Bangladesh.

which is almost two times the consumption of power sector [13]. On the other hand, among the petroleum products, high speed diesel accounts for almost $63.82 \%$ of total consumption of which nearly $52.25 \%$ is consumed by vehicle. In fiscal year 2014-2015, Eastern refinery limited has produced about 386,449 tons of high speed diesel and 245,341 tons of superior kerosene oil. In addition to this, in the year 2014-2015, the country has imported about 5,398,789.20 tons of petroleum oil including crude oil and lube base oil of total cost of BDT $27,023.27$ crores.

2.2. Compressed Natural Gas (CNG). Compressed natural gas is produced by compressing the natural gas under a pressure between $21-25 \mathrm{kPa}$. CNG is a better eco-friendly fuel compared to gasoline/diesel; hence, its use as an alternative option in replacement of gasoline or diesel to run automobiles has attracted much more attention over the world. The use of CNG in vehicles mitigates the emission of nitrous oxide, hydrocarbons, carbon monoxide, and carbon dioxide by $40 \%$, $90 \%, 80 \%$, and $25 \%$, respectively, compared to petrol or diesel fuel [14]. The need for CNG as vehicle fuel is growing very fast because of its low price and higher octane number (130) compared to petrol (93) indicating the high thermal efficiency and low emissions. In Bangladesh, $C N G$ as a vehicle fuel was introduced around 1985. The CNG run vehicles are consuming about 100.43 million cubic meters of gas per month. The demand of natural gas for CNG in next 5 years will be nearly 110-127 million cubic meters [15]. On the other hand, the share of natural gas in power generation is increasing hastily. Therefore, due to lack of natural gas production, poor gas transmission, and network distribution in Bangladesh, almost 39 districts have not previewed CNG opportunities yet. Hence, to reduce the rapid depletion of natural gas, it is necessary to give emphasis for production of $\mathrm{CNG}$ from alternative sources.

2.3. Liquefied Petroleum Gas ( $L P G)$. Liquefied petroleum gas (LPG) is a blend of propane $\left(\mathrm{C}_{3} \mathrm{H}_{8}\right)$ and butane $\left(\mathrm{C}_{4} \mathrm{H}_{8}\right)$ which is produced during the processing of natural gas and is sold 
TABLE 1: Potentials of LPG in Bangladesh [16, 17].

\begin{tabular}{lc}
\hline Supply sources & Amount (ton per year) \\
\hline Kailashtila fractionation plant, Golapgonj & 7580 \\
Eastern Refinery Ltd., Chittagong & 13200 \\
Import by private sectors & 100000 \\
Total supply & 121050 \\
\hline
\end{tabular}

in cylinder. It becomes liquid at atmospheric temperature when compressed to a pressure between 80 and 110 psi and returns into gases when the pressure is reduced adequately. The colorless and odorless LPG is easy to transport and store in liquid state and used as fuel in domestic cooking and commercial uses in the regions of insufficient pipeline. In addition to these, LPG is suitable for medium and small vehicles. Therefore, in Bangladesh, the annual demand for LPG is increasing hastily. However, the supply of LPG was only about 121 thousand tons against a demand of 500 thousand tons in year 2012 [16]. The sources of LPG in Bangladesh are presented in Table 1. Hence, the country has to import LPG to reduce the gap between demand and supply. The government has already taken initiatives to install import-based LPG storage and bottling plant in Mongla, Bagerhat, and in Chittagong [17]. In fiscal year 2014-2015, Eastern refinery limited has produced about 11,070 tons of LPG against the total consumption of 17,424 tons.

2.4. Liquefied Natural Gas (LNG). Liquefied natural gas (LNG) is produced from natural gas by condensing it artificially below a temperature of $-162^{\circ} \mathrm{C}$ and is stored in very high pressure storage tank. LNG is mainly applicable as vehicle fuel for heavy duty transports. The storage and transportation system of LNG includes floating storage and regasification unit, subsea and overland gas pipelines to transport the gas from floating terminal to the consumers. To make LNG operation economically viable, Bangladesh has to dedicate at least 0.17 Trillion cubic meters gas with an investment cost of USD 6 billion. However, considering the present gas reserve in the country, it is necessary to give emphasis on alternative option immediately. Therefore, Bangladesh has already signed an agreement with Qatar for importing about 14.16 MMCM gas in the form of LNG to meet the country's increasing demand for LNG. However, the matter of concern is that whether the country can afford the costly LNG. Bangladesh has very limited transportation facilities as LNG storage and transportation require high draught. Hence, the country has set a plan to install LNG vessel at approximately 5-6 km offshore of Moheshkhali coast because of availability of required draught. The initial plan is to supply about 4 million tons of LNG annually. Global LNG production is expected to be 450 million tons in 2020 [18].

2.5. Biodiesel. Biodiesel is nonpetroleum oil generally produced from vegetable oil, animal fats, waste cooking oil, and so forth and used as renewable source in replacement of diesel because of its nontoxicity and environmental sustainability compared to diesel [19-21]. Transesterification is the chemical process to produce biodiesel by using base catalyst, acid catalyst, enzyme catalyst, and heterogeneously catalyst. Bangladesh has promising potential of edible (mustered, cottonseed, ground nut, sesame, rapeseed, sunflower, coconut, and soybean oil) oil and nonedible (jatropha curcas, karanja, castor, neem, and algae) oil crops for biodiesel feed stocks [22]. However, nonedible vegetable oil is the most suitable for biodiesel production in Bangladesh due to the food scarcity and lack of available land for oil crops production. On the contrary, the country has many unused marginal, road, and rail side land areas which can be used for commercial biodiesel plants. Therefore, it is possible to produce about 0.52 million tons of karanja biodiesel per year utilizing this unused land which reduce country's total diesel import approximately by $21.67 \%$ [23]. On the other hand, almost 1.19 million tons of Jatropha curcas, 0.15 million tons of castor, and 1.04 million tons of pithraj can be produced annually by considering the $50 \%$ use of the available land in Bangladesh [24]. However, there is no biodiesel generation plant in Bangladesh yet.

\section{Biogas to Automobile Fuels}

3.1. Bio-CNG. Bio-CNG, a methane rich compressed fuel, is also known as compressed biomethane. Bio-CNG is produced from pure biogas containing more than $97 \%$ methane at a pressure of $20-25 \mathrm{MPa}$. It is very similar to the regular $\mathrm{CNG}$ in terms of its fuel properties, economy, engine performance, and emissions. Like regular CNG, bio-CNG has high octane number which results in the high thermal efficiency. The performance of a constant speed internal combustion engine using CNG and bio-CNG was compared and it was noted that their engine performances were almost similar in terms of brake power output, specific gas consumption, and thermal efficiency [25]. A typical bio-CNG station comprises a biogas purification unit, a multistage compressor, and a high pressure storage system [26]. Because of the shorter driving range of bio-CNG compared to diesel fuel, the consumers have to install additional fuel cylinders to extend their driving range [27]. Bio-CNG can be injected into the CNG grid and blended with CNG. However, if the current CNG grid is inadequate, bio-CNG can be transported by trucks or in cylinder from the locations of production to the filling stations. From the literature, bio-CNG delivers greater environmental benefits than other traditional vehicle fuels as well as biodiesel and bioethanol [28-30]. Considering both technical and financial performance production of bio-CNG for vehicle fuel is at least feasible as it is produced from renewable wastes [31]. Therefore, the huge potentiality of different wastes in Bangladesh can make bio-CNG production a viable option.

3.2. Liquefied Biogas (LBG). Biomethane from biogas can be liquefied to a fuel called liquefied biomethane (LBM) or LBG which has the similar characteristics to LNG. The conversion of LBM from biomethane requires a combination of high pressures and low temperatures and is a rather energy intensive process. LBM has the energy content of about $70 \%$ that of gasoline and can be used as a vehicle fuel in replacement of conventional vehicle fuel. Commonly 
TABLE 2: Bioenergy potential in Bangladesh, 2012-2013 [40].

\begin{tabular}{lccc}
\hline Biomass resources & Biomass generation (million tons) & Dry biomass recovery (million tons) & Energy content (PJ) \\
\hline Agricultural residues & 94.10 & 36.48 & 582.33 \\
Animal manure & 72.81 & 26.20 & 363.30 \\
Poultry excreta & 10.70 & 2.68 & 36.12 \\
Human excreta & 5.38 & 5.38 & 56.99 \\
MSW & 13.38 & 5.15 & 95.61 \\
Forest residues & 17.44 & 14.32 & 210.64 \\
Total & 213.81 & 90.21 & 1344.99 \\
\hline
\end{tabular}

used LBG production methods include cryogenic technology, liquefaction, and pressure letdown. During the liquefaction of biogas even a small amount of impurity can cause substantial difficulties and presence of oxygen can also cause danger of explosions. Therefore, biogas has to contain less than $25 \mathrm{ppm}$, $4 \mathrm{ppm}$, and $1 \mathrm{ppm}$ of $\mathrm{CO}_{2}, \mathrm{H}_{2} \mathrm{~S}$, and $\mathrm{H}_{2} \mathrm{O}$, respectively, to produce liquefied biomethane [32]. Ignoring the energy input for liquefaction, it has been estimated that 1,000 cubic feet of gas yield about 10 gallons of LBM. On the other hand, assuming $10 \%$ losses, a plant producing about 70,000 cubic feet of biogas per day can generate approximately 500 gallons of LBG per day [33]. There is not much practical experience with this option because of its high capital and operating cost of liquefaction equipment though it has a much higher energy density in comparison to bio-CNG. Bangladesh needs to import the technology from Germany/ Sweden for production of LBG from biogas available in the country.

3.3. Syngas. Syngas is a mixture of fuel gases which mainly contains hydrogen, carbon monoxide, and a small amount of carbon dioxide. Carbon containing fuels are the major sources of syngas generally produced by gasification process. Syngas can be produced from pure biogas through any of the three reforming process, for example, dry reforming, steam reforming, and partial oxidative reforming or any combination of these processes [34]. Steam reforming can produce high purity hydrogen as clean vehicle fuel commercially [35]. Dry reforming and steam reforming are endothermic process, while partial oxidative reforming is an exothermic process. In addition to this, syngas can be converted into methanol and dimethyl ether and further upgraded into transport fuel like diesel, jet fuel, gasoline, and so forth through Fischer-Tropsch synthesis method [26]. The calorific value of the syngas varies depending on the use of agent for gasification process. However, the use of oxygen or steam can increase the calorific value of syngas.

3.4. Biomethanol/Biogasoline. Gasoline is produced by upgrading methanol through methanol-to-gasoline (MTG) process. In recent years, the attention has been increased for biomethanol production from biogas through partial oxidation of methane, photocatalytic conversion, biological conversion, and biogas reforming to syngas and hence to methanol via FTS method [36]. Partial oxidation of methane is most attractive and commonly used technology for biomethanol. It has been estimated that biomethanol can mitigate greenhouse gas emissions by $25-40 \%$ compared to methanol produced from fossil fuels. In the year 2012, global biomethanol production was about 0.2 million tons and expected to be more than 1 million tons in the next few years [8]. Biomethanol is converted into aromatic hydrocarbon known as biogasoline by two steps of exothermic MTG process [37]. Biogasoline has almost twice the energy content of that of biomethanol and has higher vapor pressure compared to biomethanol. Biogasoline or blending of biogasoline and biomethanol can be directly used as transport fuel in vehicle.

\section{Prospective Analysis of Bio-CNG in Bangladesh}

4.1. Potential of Biogas in Bangladesh. Biogas is a nonfossil, colorless, combustible gas containing about $40-70 \%$ methane. Biogas is produced by anaerobic digestion with anaerobic bacteria or fermentation of biodegradable materials such as manure, municipal waste and sewage, green waste, plant material, and crops [38, 39]. The biogas has combustion properties like natural gas as it burns at about $800^{\circ} \mathrm{C}$ with an ignition temperature of $650-750^{\circ} \mathrm{C}$ compared to $1000^{\circ} \mathrm{C}$ for natural gas $[4,17]$. To cope with the present world, Bangladesh is going very fast by using biogas technology to produce biogas. Bangladesh has huge potential of biodegradable biomass resources including agricultural residues, animal manure, municipal solid waste, and human excreta to produce biogas. In the year 2012-2013, the country had almost 23.241 million cattle, 25.212 million goat, 246.60 million chicken, and 46.635 million duck [40]. These large numbers of livestock can produce huge amount of biomass residues. Additionally, field residues and process residues from agriculture are another promising candidate for biomass generation. It has been estimated that one ton of cattle excreta, sheep and goat excreta, poultry excreta, human excreta, crop residue, and organic fraction of MSW can generate almost $33 \mathrm{~m}^{3}, 58 \mathrm{~m}^{3}, 78 \mathrm{~m}^{3}, 50 \mathrm{~m}^{3}, 60 \mathrm{~m}^{3}$, and $66 \mathrm{~m}^{3}$ of biogas, respectively [41-44]. Taking into account the above biogas generation rate, it has been calculated that the country had about 213.81 million tons of biomass generation potential (Table 2) in the fiscal year 2012-2013 which could produce nearly 7.6775 billion $\mathrm{m}^{3}$ biogas.

If only cow dung is brought under biogas production plant, then it could be possible to produce about 2.54 billion $\mathrm{m}^{3}$ of biogas in 2012-2013 which is equivalent to 1.455 
TABLE 3: Plant based daily biogas production data in Bangladesh [47].

\begin{tabular}{lcccc}
\hline $\begin{array}{l}\text { Plant size } \\
\text { (daily gas production), } \mathrm{m}^{3}\end{array}$ & Operation hours per day & Cow dung, Kg & Poultry stool, Kg & Construction cost, (BDT) \\
\hline 1.6 & $3-4$ & 43 & 23 & 26000 \\
2.0 & $4-5$ & 54 & 28 & 32000 \\
2.4 & $5-6$ & 65 & 34 & 36000 \\
3.2 & $7-8$ & 87 & 35 & 43000 \\
4.8 & $10-12$ & 139 & 68 & 52000 \\
\hline
\end{tabular}



FIGURE 2: Biogas generation potential from different biomass wastes.

billion liters of diesel. On the other hand, poultry feces had the potential to produce approximately 0.749 billion $\mathrm{m}^{3}$ of biogas in 2012-2013 as presented in Figure 2. However, if $50 \%$ of the total biomass is considered for biogas generation, then it is possible to generate almost 3.83875 billion $\mathrm{m}^{3}$ of biogas which is equivalent to 2.20 billion diesel fuel. In Bangladesh, most of the biogas plants constructed are fixed dome type biogas plant based on cow dung and poultry litter of capacity between 1.6 and $4.8 \mathrm{~m}^{3}$ as depicted in Table 3 . Up to October 2014, almost 79,612 domestic biogas plants have been constructed by technical and financial assistance of various government and nongovernment organizations [45]. However, the country has a potential of 4 million small-scale biogas digesters. In Bangladesh, first commercial biogas plant was constructed by Paragon Poultry Ltd. in Mymensingh and Gazipur in 2010 which are producing 38.23 cubic feet and 76.46 cubic feet of biogas, respectively [46]. In addition to these, IDCOL has financed 8 biogas based power plants using poultry litters for gas production. Recently, Bangladesh has about 215,000 poultry farms and 15,000 cattle farms which may be an excellent source for biogas.

4.2. Biogas to Bio-CNG Conversion Technology/Process. Biogas produced from anaerobic digestion of biodegradable biomass contains significant amount of impurities like water, $\mathrm{N}_{2}, \mathrm{O}_{2}, \mathrm{H}_{2} \mathrm{~S}, \mathrm{NH}_{3}$, and $\mathrm{CO}_{2}$ and so forth. Therefore, biogas has to be purified prior to the conversion into bioCNG. Generally, pressurized water scrubbing, pressure swing adsorption, chemical absorption, membrane permeation, temperature swing adsorption, cryogenic approach, physical absorption, and biological filtration methods are used to

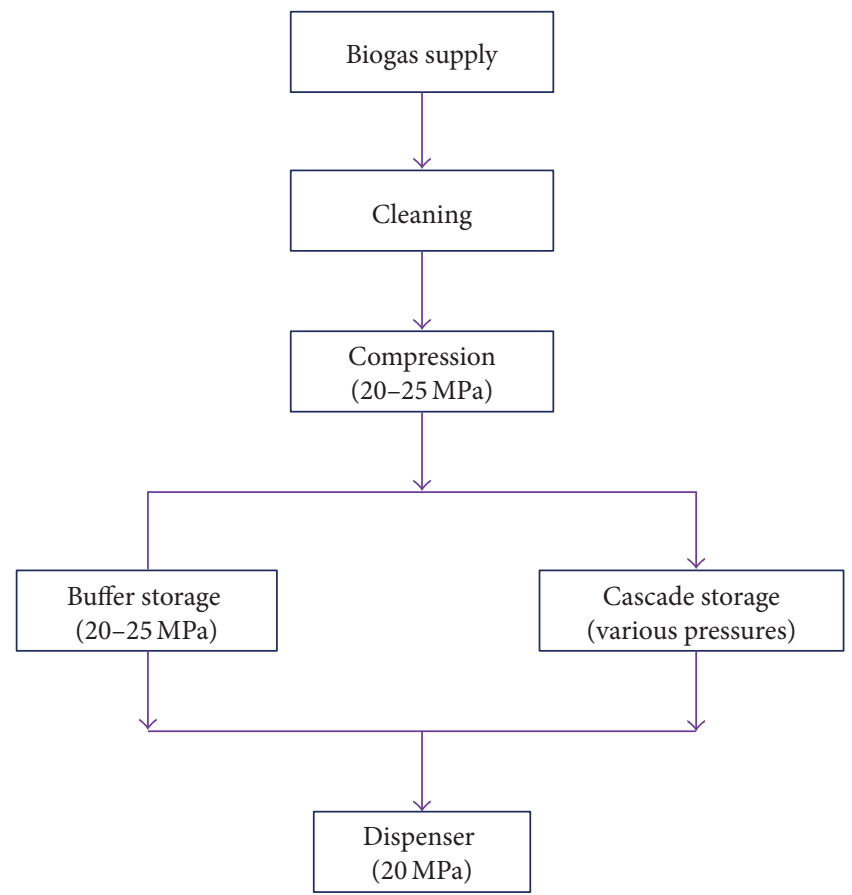

FIGURE 3: Outline of bio-CNG production, storage, and distribution [49].

purify the biogas before conversion [48]. However, pressurized water scrubbing is the most commonly used method as it offers several advantages and higher percentages of $\mathrm{CH}_{4}$ purity compared to the other purifying methods [49]. Table 4 presents the process description of some common biogas cleaning methods. In context of Bangladesh, water scrubbing and membrane separation technology are the most feasible technology for biogas upgradation based on the technical availability and maintenance costs.

Cleaned biogas containing more than $97 \% \mathrm{CH}_{4}$ and less than $2 \% \mathrm{O}_{2}$ is considered for production of bio-CNG. Generally, two approaches named physical (compression and liquefaction) and chemical approach (catalytic reforming and Fischer-Tropsch synthesis) are applied for this conversion. Pure biogas then undergoes a high compression pressure between 20 and $25 \mathrm{MPa}$ (Figure 3) and converts into bioCNG which occupies less than $1 \%$ of its normal volume. It is required to store bio-CNG as it affects vehicle filling time, filling completeness, and energy consumption [53]. Typically, two storage systems such as buffer storage and cascade storage are used in filling station. The buffer storage system maintains 







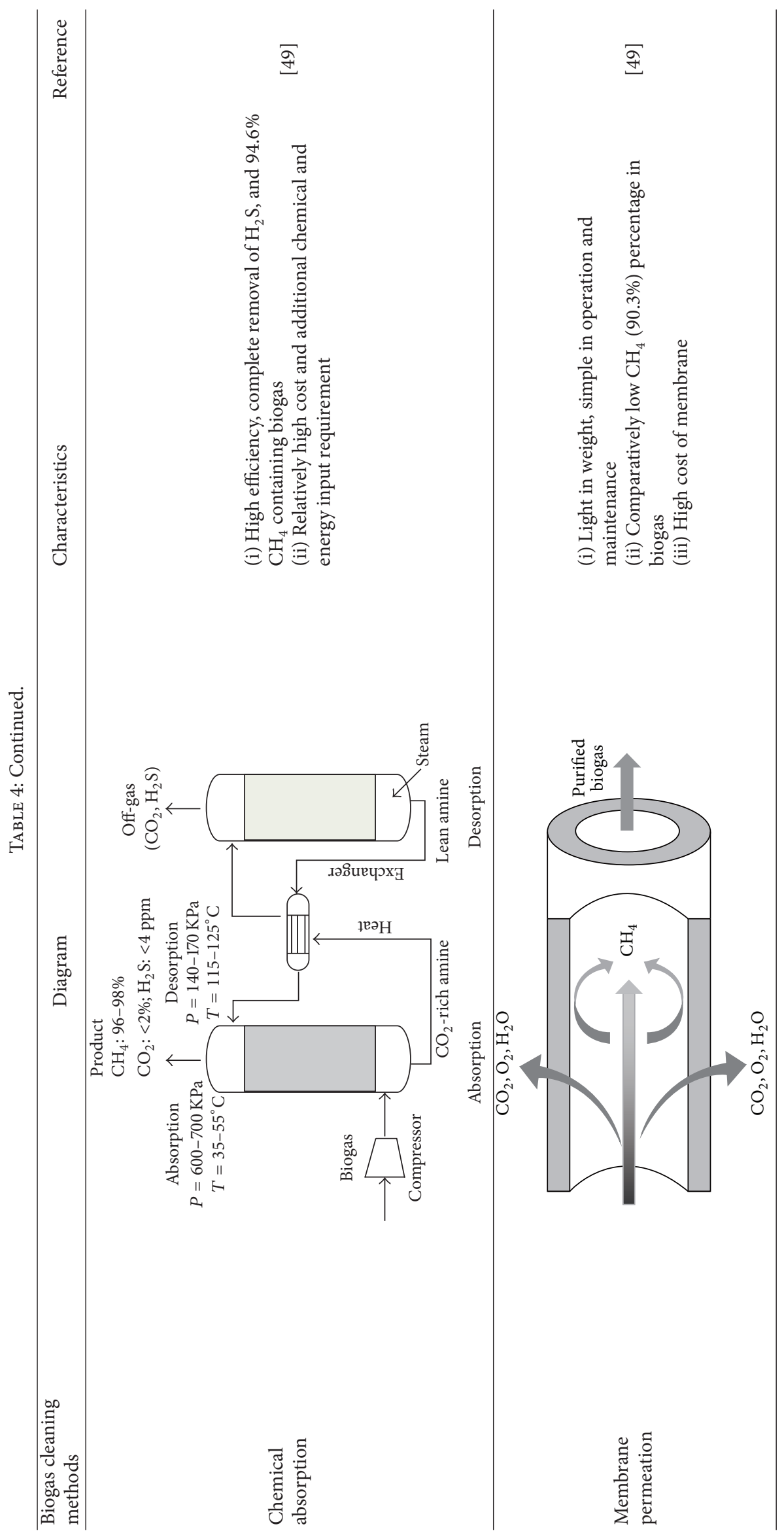




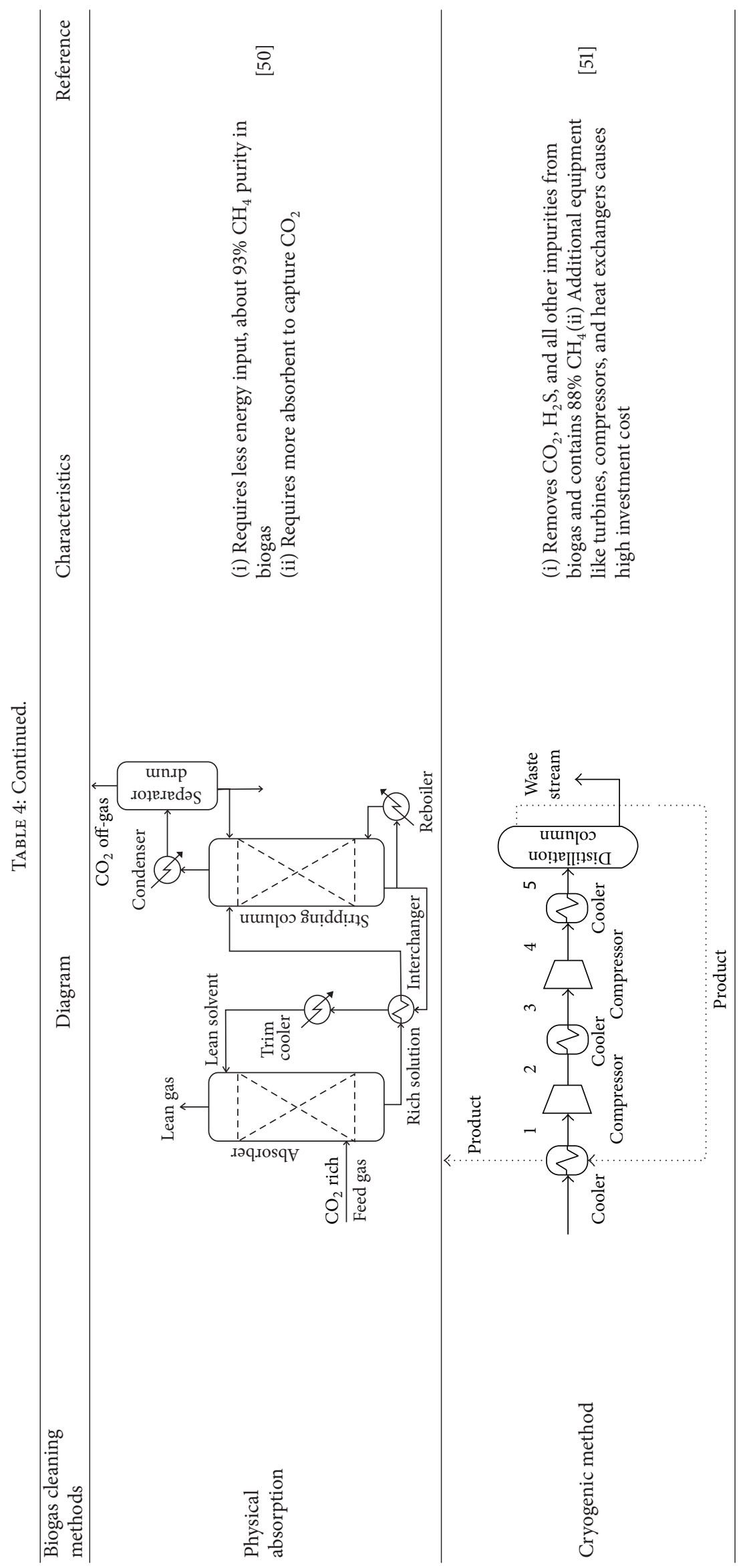









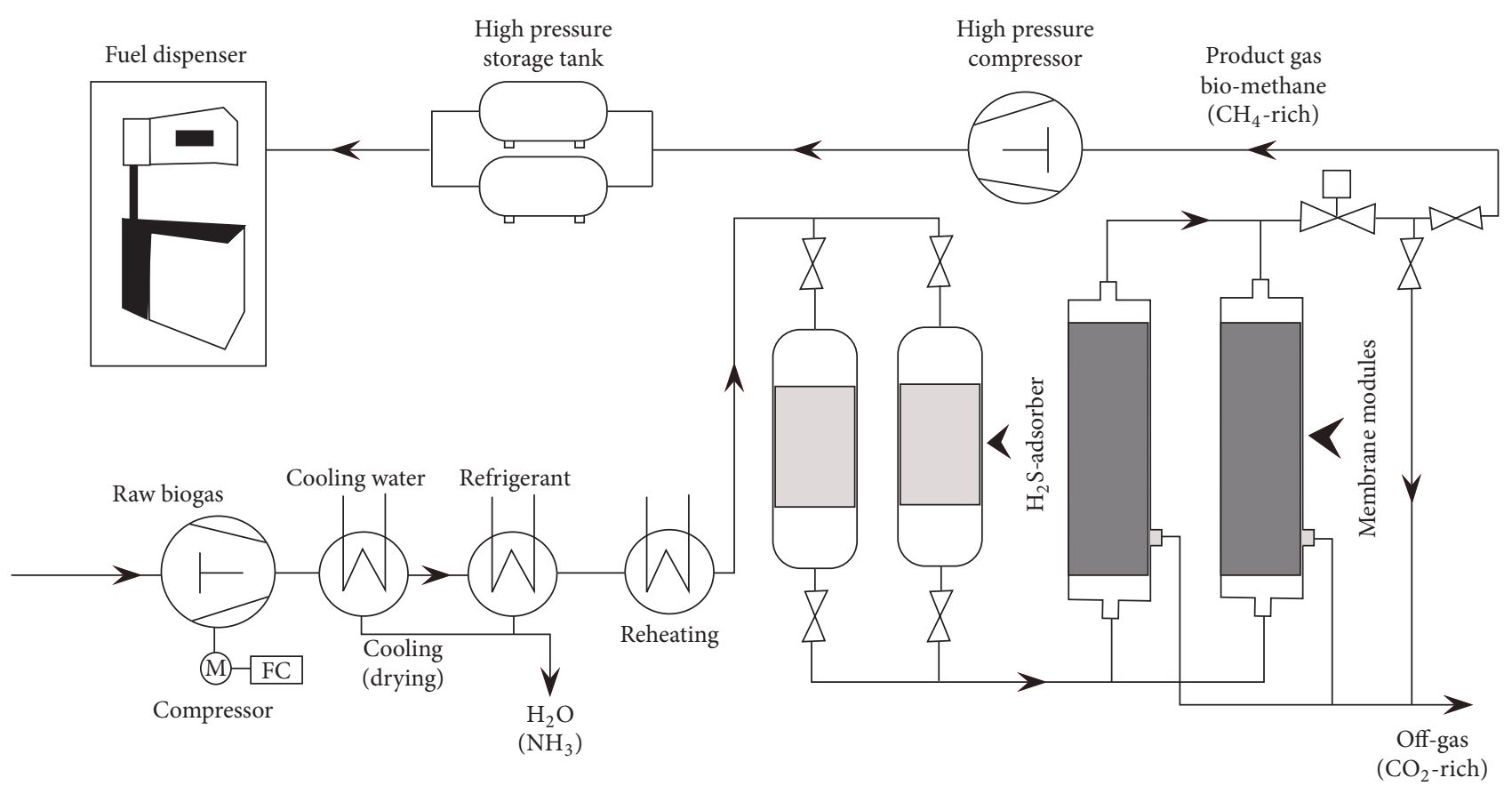

FIGURE 4: Schematic diagram of total bio-CNG process and vehicle fueling method [55].

the pressure of CNG in the range of $20-25 \mathrm{MPa}$ and provides CNG with a maximum pressure of $20 \mathrm{MPa}$ to a vehicle's onboard cylinders. In this case, all filling station reservoirs are connected and maintained at the same pressure [27].

On the contrary, the cascade storage system contains three reservoirs of low, medium, and high pressure and provides CNG in three steps to vehicle's on-board cylinders. In this case, the vehicle's cylinders are connected to the low pressure reservoir firstly and then to the medium pressure reservoir when the pressure is increased into the cylinder and finally to the high pressure reservoir for completing the filling process. In comparison with the cascade reservoir, the buffer reservoir offers fast filling and charges $80 \%$ more gas [54].

4.3. Bio-CNG Vehicle Technology. Bio-CNG technology consists of the refueling station and vehicle technology. BioCNG refueling station is much more complicated than the conventional diesel/petrol refueling station as all the components of bio-CNG vehicles and the refueling station are required to be maintained at a high pressure. On the other hand, slow filling refueling station is simpler than the fast filling refueling station which normally provides fuel overnight. Both the petrol (spark ignition) engine and diesel (compression ignition) engine driven vehicle can be converted to bio-CNG driven vehicle by the modification of some features through retrofitting. It offers the advantage of switching the option of using bio-CNG or conventional fuel. Figure 4 illustrates the process pathways of bio-CNG production and vehicle fueling in refueling station. In this case, a new fuel tank with a regulator, fuel lines, and new secondary injector are required to convert conventional fuel vehicle to bio-CNG vehicle. The regulator reduces tank pressure from 3,600 psi to $125 \mathrm{psi}$ and the secondary injector

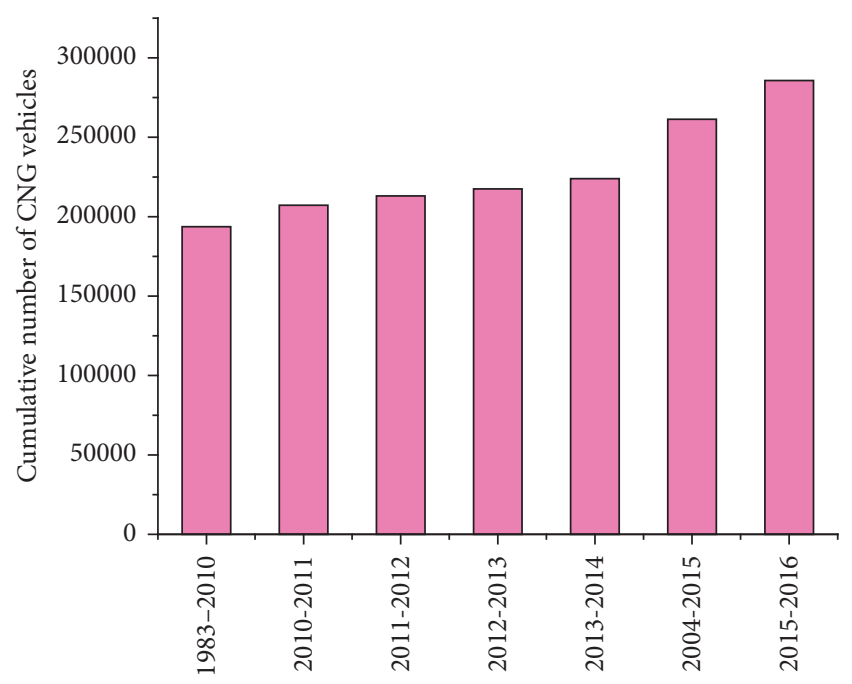

FIGURE 5: Growth of CNG vehicles in Bangladesh.

injects the bio-CNG into the cylinder through fuel lines for combustion to produce energy.

4.4. Possibility of Bio-CNG in Bangladesh. Recently, in Bangladesh the consumption of $\mathrm{CNG}$ as transportation fuel and the number of CNG based vehicles are growing very fast because of its low cost and environmental sustainability. Figure 5 shows the cumulative growth of CNG vehicles including the number of converted CNG vehicles and the number of exported CNG vehicles. However, this high rate of consumption causes the threat for future reserve and forces us to harness the renewable and environmental friendly options 




Figure 6: Bio-CNG potential from various biomass resources.

for automobile fuel. It is obvious that some countries such as Germany, Austria, and the United States have proved that bio-CNG can take the place of fossil fuels as transportation fuel. However, in Bangladesh there are not so many industrial plants for biogas purification and bio-CNG production. Only, Effat BioCNG Limited has developed a technology based on water scrubbing for purifying the biogas by removing carbon dioxide and hydrogen sulphide and for producing bio-CNG with less than $2 \%$ methane loss.

In the fiscal year 2012-2013, total biogas (7.6775 billion $\mathrm{m}^{3}$ ) available in the country could produce about 3.4549 billion $\mathrm{kg}$ $\left(1 \mathrm{~m}^{3}\right.$ biogas $=0.45 \mathrm{~kg}$ bio-CNG $)$ bio-CNG which is equivalent to 5.088 billion $\mathrm{m}^{3}\left(\rho_{\text {bio-CNG }}=0.679 \mathrm{~kg} / \mathrm{m}^{3}\right)$ of bio$\mathrm{CNG}$. Figure 6 shows the amount of bio-CNG produced from different biomass wastes. It is estimated that 1 liter of octane is equivalent to $0.81 \mathrm{~m}^{3}$ of bio-CNG, 1 liter of petrol is equivalent to $0.80 \mathrm{~m}^{3}$ of bio-CNG, and 1 liter of diesel is equivalent to $0.97 \mathrm{~m}^{3}$ of bio-CNG. Accordingly, total bio-CNG potential in Bangladesh is equivalent to 5.25 billion liters of diesel, 6.36 billion liters of petrol, and 6.28 billion liters of octane. Therefore, Bangladesh shows the huge potentiality of bioCNG production for alternative vehicle fuel. Sufficient feed material is the prerequisite for the continuous production of bio-CNG. It is difficult to collect feed materials from villages because of its high transportation cost. On the other hand, the six municipalities in Bangladesh produce about 7690 tons [60] of waste per day which can be available to generate fuel for vehicle running in the municipality. It has been estimated that the organic municipal solid waste available only in Dhaka can produce almost $41,830 \mathrm{~m}^{3}$ per day of biogas equivalent to $27,721.4 \mathrm{~m}^{3}$ of bio-CNG. Furthermore, the rate of migration of people to municipality is increasing very fast which can increase the quantity of organic waste as well. In addition, the inclusion of human manure for biogas production can be also a secure feed material in long run of bio-CNG plant in the municipality.

\section{Competitive Analysis of Bio-CNG as Transportation Fuel}

The feasibility of biogas conversion into bio-CNG as transportation fuel primarily depends on some key factors such as economic, technical, environmental, and safety. Fuel properties of bio-CNG are nearly the same as regular CNG and also competitive compared to the other automobile fuels such as diesel and petrol. The percentage of methane (>97\%) in bioCNG is higher than that of natural gas (93\%) produced from different gas fields in Bangladesh. Besides this, the calorific value of bio-CNG is about $52 \mathrm{MJ} / \mathrm{kg}$ which is higher than the calorific value of petrol $(48 \mathrm{MJ} / \mathrm{kg})$ and diesel $(44.8 \mathrm{MJ} / \mathrm{kg})$ as revealed in Table 5. The amount of energy cost in $\mathrm{kJ} / \mathrm{BDT}$ is almost 3.5 times that of petrol and 2.25 times of diesel. Furthermore, in Bangladesh the cost of petrol and diesel fuel is significantly high as about BDT 96 per liter and BDT 68 per liter for petrol and diesel, respectively. On the other hand, the price of CNG and bio-CNG is approximately BDT 30 per $\mathrm{m}^{3}$ and BDT 14.22 per $\mathrm{m}^{3}$, respectively [13, $15,61,62]$. Considering the equivalent ratio of bio-CNG to other transportation fuels, the use of 1 liter of bio-CNG as automobile fuel in replacement of 1 liter of petrol and 1 liter of diesel can save about BDT 84.62 and BDT 54.20, respectively. Additionally, bio-CNG contains negligible amount of impurities including less than $4 \% \mathrm{CO}_{2}$ and $8 \mathrm{ppm} \mathrm{H}_{2} \mathrm{~S}$ with no other impurities which are much lower than diesel and petrol fuel and responsible for up to $90 \%$ emission reduction compared to the conventional transportation fuel. Germany, Netherland, and Sweden are the most biomethane producing countries in the world. Sweden can be a role model for Bangladesh as the country is using $97 \%$ of bio-CNG for vehicle fuel, while Germany is using $1.4 \%$ of total bio-CNG successfully. Therefore, it is clearly depicted that bio-CNG is a rising candidate for automobile fuel. Although bio-CNG has several advantages over the conventional vehicle fuel, it has number of disadvantages. Because of decentralized feed material availability, the production cost of bio-CNG can be very high nowadays. Additionally, the lack of awareness about the suitability of bio-CNG over the other fuels hinders the support from the government as well as the other investors.

\section{Issues and Challenges of Bio-CNG Technology in Bangladesh}

It is well evident that the use of bio-CNG as automobile fuel provides significant benefits in economic, emissions, and engine performance perspective. However, the successful implementation of this technology in developing country like Bangladesh is a great challenge. Requirement of sufficient amount of feed materials, upgradation of equipment and the cost, lack of technically sound man power, and refueling infrastructure are considered the significant barriers to the deployment of bio-CNG as vehicle fuel. Typically, a bio-CNG plant requires a biogas unit, purification unit, compression unit, and storage unit with other accessories maintained at high pressure. Lack of technology standardization is the main stumbling block for production of cost efficient renewable bio-CNG. Although Bangladesh has huge potential of biogas generation resources, there is insufficiency of industrial scale biogas plants with high level of automation to produce bioCNG because of its high investment cost and lack of standard technology. In addition to this, almost $75 \%$ of total municipal waste in Bangladesh are unused and go for landfilling because 
TABLE 5: Competitive analysis of bio-CNG among other fuels in Bangladesh [4, 13, 56-59].

\begin{tabular}{lccc}
\hline Fuel & Calorific value $(\mathrm{MJ} / \mathrm{Kg})$ & Tariff/rate/cost $(\mathrm{BDT} / \mathrm{Kg})$ & Cost of energy $(\mathrm{KJ} / \mathrm{BDT})$ \\
\hline CNG & 52 & 42.10 & 1232.81 \\
Bio-CNG & 52 & 40.91 & 1271.08 \\
LPG (commercial) & 46 & 56 & 821.43 \\
Petrol & 48 & 133.44 & 359.71 \\
Diesel & 44.8 & 79.97 & 560.21 \\
\hline
\end{tabular}

of lack of proper technical knowledge and sufficient human resources to produce useful energy like bio-CNG. Besides this, in Bangladesh there are no specific guidelines and rules for renewable energy use. Additionally, there is no inclusion of legal, regulatory, and policy framework for bio-CNG conversion from waste in country's national energy policy.

\section{Concluding Remarks}

In Bangladesh, the energy shortage is the main hindrance for the development in every sector. Due to high price and crisis of crude oil, petroleum products and natural gas resources, the concept of using methane as a feed stock to produce transportation fuels has greatly increased. This paper has assessed that Bangladesh has about 7.6775 billion $\mathrm{m}^{3}$ of biogas potential that can produce 5.088 billion $\mathrm{m}^{3}$ of bio-CNG. If bio-CNG is used as automobile fuel in replacement of regular CNG or diesel fuel, it can save almost 5.088 billion $\mathrm{m}^{3}$ of regular CNG or 5.25 billion liters of diesel fuel. Although the country has available raw materials for bio-CNG production, it requires special attention to utilize these resources properly. Therefore, the government should come forward with some concrete bio-CNG implementation strategies considering its necessity. Firstly, it is mandatory to prepare policy and regulatory framework for the production and utilization of bio-CNG instead of traditional vehicle fuel. Additionally, it is necessary to take initiatives for the development of bioCNG distribution network right now and to motivate the nongovernment organizations for construction of bio-CNG plants.

\section{Conflicts of Interest}

The authors declare that they have no conflicts of interest.

\section{References}

[1] J.-P. Rodrigue, C. Comtois, and B. Slack, The Geography of Transport Systems, Routledge, Abingdon, UK, 4th edition, 2013.

[2] The National Academies of Science, Engineering and Medicine, 2016, http://needtoknow.nas.edu/.

[3] K. D. Patil, U. P. F. Pathan, P. S. M. Mahajan, and P. D. R. Satpute, "Alternative Fuel Public Transport Buses," International Journal of Engineering Research and Development, vol. 10, no. 12, pp. 2935, 2014.

[4] P. Jain, "Renewable Natural Gas-Bio CNG, in: Sustain, Outlook," 2012, http://sblf.sustainabilityoutlook.in/file_space/SBLF Summit Presentations 2012/Green Brick Eco Solutions_Prasun Joshi .pdf.
[5] C. Voell, "Feasibility of Small Scale Biogas-to-CNG Vehicle Fuel Projects," 2016, http://biocng.us/.

[6] Energy Vision, "Renewable Natural Gas (RNG): The Solution to a Major Transportation Challenge," 2016, http://energy-vision .org/ev-publications/EV-RNG-Facts-and-Case-Studies.pdf.

[7] The Hindu, "New source for bio-CNG production," 2016, http:// www.thehindu.com/todays-paper/tp-national/tp-otherstates/ new-source-for-biocng-production/article1283967.ece.

[8] "International Energy Agency (IEA)," 2016, http://www.iea .org/.

[9] 100\% Biogas for Urban Transport in Linköping, Sweden Biogas in Buses, Cars and Trains, 2005.

[10] P. K. Halder, N. Paul, M. U. H. Joardder, and M. Sarker, "Energy scarcity and potential of renewable energy in Bangladesh," Renewable and Sustainable Energy Reviews, vol. 51, pp. 16361649, 2015.

[11] British Petroleum, "Statistical Review of World Energy 2015," 2016, http://www.bp.com/en/global/corporate/energyeconomics/statistical-review-of-world-energy.html.

[12] W. W. Irion and O. S. Neuwirth, "Oil refining," in Ullmann's Encyclopedia of Industrial Chemistry, Wiley-VCH Verlag GmbH \& Co. KGaA, Weinheim, Germany, 2000.

[13] "Bangladesh Petroleum Corporation (BPC)," 2016, http://www .bpc.gov.bd/.

[14] S. Wakdikar, "Compressed natural gas: A problem or a solution," Current Science, vol. 82, 2002.

[15] "Rupantarita Prakritik Gas Company Limited (RPGCL)," 2016, http://www.rpgcl.org.bd/.

[16] Government of the People of Republic of Bangladesh (GOB), "Ministry of Finance, Finance Division, Sector Road map: Second Update," 2016, http://mof.gov.bd/en/budget/12_13/power/ power_energy_en.pdf.

[17] B. Imam, Energy Resources of Bangladesh: Natural Gas, Oil, Coal, University Grants Commission of Bangladesh, Dhaka, Bangladesh, 2013.

[18] D. A. Wood, "A review and outlook for the global LNG trade," Journal of Natural Gas Science and Engineering, vol. 9, pp. 16-27, 2012.

[19] B. K. Barnwal and M. P. Sharma, "Prospects of biodiesel production from vegetable oils in India," Renewable and Sustainable Energy Reviews, vol. 9, no. 4, pp. 363-378, 2005.

[20] J. Van Gerpen, "Biodiesel processing and production," Fuel Processing Technology, vol. 86, no. 10, pp. 1097-1107, 2005.

[21] L. C. Meher, D. Vidya Sagar, and S. N. Naik, "Technical aspects of biodiesel production by transesterification-a review," Renewable and Sustainable Energy Reviews, vol. 10, no. 3, pp. 248-268, 2006.

[22] M. Habibullah, H. H. Masjuki, M. A. Kalam et al., "Potential of biodiesel as a renewable energy source in Bangladesh," Renewable and Sustainable Energy Reviews, vol. 50, pp. 819-834, 2015. 
[23] P. K. Halder, N. Paul, and M. R. Beg, "Prospect of pongamia pinnata (karanja) in bangladesh: a sustainable source of liquid fuel," Journal of Renewable Energy, vol. 2014, pp. 1-12, 2014.

[24] A. B. M. A. Islam, "Trees to Produce Biofuel For Combating The Energy Crisis In Bangladesh, University of Flensburg," 2008, http://slidegur.com/doc/3027232/bio-energy-utilization-in-developing-countries-and-future.

[25] R. Chandra, V. K. Vijay, P. M. V. Subbarao, and T. K. Khura, "Performance evaluation of a constant speed IC engine on CNG, methane enriched biogas and biogas," Applied Energy, vol. 88, no. 11, pp. 3969-3977, 2011.

[26] Y. Li and L. Yang, "Converting Biogas to Transportation Fuels, Ohio State University Extension," 2014.

[27] S. Clarke, "Vehicle Conversion to Natural Gas or Biogas, Ministry of Agriculture, Food and Rural Affairs, Ontario," 2012, http://www.omafra.gov.on.ca/english/engineer/facts/12-043 .htm.

[28] B. M. Smyth, J. D. Murphy, and C. M. O'Brien, "What is the energy balance of grass biomethane in Ireland and other temperate northern European climates?" Renewable and Sustainable Energy Reviews, vol. 13, no. 9, pp. 2349-2360, 2009.

[29] T. Patterson, R. Dinsdale, and S. Esteves, "Review of energy balances and emissions associated with biomass-based transport fuels relevant to the United Kingdom context," Energy \& Fuels, vol. 22, pp. 3506-3512, 2008.

[30] J. D. Murphy and N. Power, "Technical and economic analysis of biogas production in Ireland utilising three different crop rotations," Applied Energy, vol. 86, no. 1, pp. 25-36, 2009.

[31] T. Patterson, S. Esteves, R. Dinsdale, and A. Guwy, "An evaluation of the policy and techno-economic factors affecting the potential for biogas upgrading for transport fuel use in the UK," Energy Policy, vol. 39, no. 3, pp. 1806-1816, 2011.

[32] D. Brown, J. Shi, and Y. Li, "Comparison of solid-state to liquid anaerobic digestion of lignocellulosic feedstocks for biogas production," Bioresource Technology, vol. 124, pp. 379-386, 2012.

[33] K. Krich, D. Augenstein, J. Benemann, B. Rutledge, Salour, and D., "Biomethane from Dairy Waste: A Sourcebook for the Production and Use of Renewable Natural Gas in California," 2005, http://suscon.org/pdfs/cowpower/biomethaneSourcebook/Full_Report.pdf.

[34] A. Serrano-Lotina and L. Daza, "Influence of the operating parameters over dry reforming of methane to syngas," International Journal of Hydrogen Energy, vol. 39, no. 8, pp. 4089-4094, 2014.

[35] A. Boyano, T. Morosuk, A. M. Blanco-Marigorta, and G. Tsatsaronis, "Conventional and advanced exergoenvironmental analysis of a steam methane reforming reactor for hydrogen production," Journal of Cleaner Production, vol. 20, no. 1, pp. 152-160, 2012.

[36] S. B. Jones and Y. Zhu, "Techno-economic Analysis for the Conversion of Lignocellulosic Biomass to Gasoline via the Methanol-to-Gasoline (MTG) Process," Tech. Rep. PNNL18481, 2009.

[37] W.-H. Cheng, Methanol Production and Use, CRC Press, Boca Raton, Fla, USA, 1994.

[38] S. Kalambe, R. S. Sapkal, and V. S. Sapkal, "Low Pressure Separation Technique of Biogas Into Ch4 and Co2 Employing Pdms Membrane," International Journal of Engineering and Advanced Technology, vol. 3, pp. 311-315, 2012.

[39] National Non-Food Crops Centre (NNFCC), "Renewable Fuels and Energy Factsheet: Anaerobic Digestion,” 2016, http://www.nnfcc.co.uk/.
[40] P. K. Halder, N. Paul, and M. R. A. Beg, "Assessment of biomass energy resources and related technologies practice in Bangladesh," Renewable and Sustainable Energy Reviews, vol. 39, pp. 444-460, 2014.

[41] L. Song, L. Deng, Y. Yin, X. Pu, and Z. Wang, "Biogas production potential and characteristics of manure of sheep, duck and rabbit under anaerobic digestion," Transactions from the Chinese Society of Agricultural Engineering, vol. 26, pp. 277$282,2010$.

[42] A. Schunurer and A. Jarvis, "Microbiological Handbook for Biogas Plants," 2009.

[43] F. F. Tatlidil, Z. Bayramoglu, and D. Akturk, "Animal manure as one of the main biogas production resources: Case of Turkey," Journal of Animal and Veterinary Advances, vol. 8, no. 12, pp. 2473-2476, 2009.

[44] M. S. Rao, S. P. Singh, A. K. Singh, and M. S. Sodha, "Bioenergy conversion studies of the organic fraction of MSW: Assessment of ultimate bioenergy production potential of municipal garbage," Applied Energy, vol. 66, no. 1, pp. 75-87, 2000.

[45] P. K. Halder, N. Paul, M. U. H. Joardder, M. Z. H. Khan, and M. Sarker, "Feasibility analysis of implementing anaerobic digestion as a potential energy source in Bangladesh," Renewable and Sustainable Energy Reviews, vol. 65, pp. 124-134, 2016.

[46] Paragon Group, "Paragon Poultry Ltd," 2016, http://paragongroup-bd.com/.

[47] Infrastructure Development Company Limited (IDCOL), 2016, http://www.idcol.org/.

[48] O. W. Awe, Y. Zhao, A. Nzihou, D. P. Minh, and N. Lyczko, "A review of biogas utilisation, purification and upgrading technologies," Waste and Biomass Valorization, vol. 8, no. 2, pp. 267-283, 2017.

[49] L. Yang, X. Ge, C. Wan, F. Yu, and Y. Li, "Progress and perspectives in converting biogas to transportation fuels," Renewable and Sustainable Energy Reviews, vol. 40, pp. 1133-1152, 2014.

[50] F. Rossi, A. Nicolini, M. Palombo, B. Castellani, E. Morini, and M. Filipponi, "An innovative configuration for $\mathrm{CO} 2$ capture by high temperature fuel cells," Sustainability (Switzerland), vol. 6, no. 10, pp. 6687-6695, 2014.

[51] S. V. Khedkar and N. Bhautik, "Studies in Purification of Biogas Using Al Gas in Sewage Waste Water- A Review Paper," International Journal of Pure and Applied Sciences and Technology, vol. 3, pp. 95-108, 2015.

[52] S. G. Ramalingam, P. Pré, S. Giraudet et al., "Recovery comparisons-Hot nitrogen Vs steam regeneration of toxic dichloromethane from activated carbon beds in oil sands process," Journal of Hazardous Materials, vol. 205-206, pp. 222228, 2012.

[53] M. Farzaneh-Gord, M. Deymi-Dashtebayaz, and H. R. Rahbari, "Studying effects of storage types on performance of CNG filling stations," Journal of Natural Gas Science and Engineering, vol. 3, no. 1, pp. 334-340, 2011.

[54] M. Farzaneh-Gord and S. Branch, "Real and ideal gas thermodynamic analysis of single reservoir filling process of natural gas vehicle cylinders," Journal of Theoretical and Applied Mechanics, vol. 41, pp. 21-26, 2011.

[55] M. Miltner, A. Makaruk, H. Bala, and M. Harasek, "Biogas upgrading for transportation purposes - Operational experiences with Austrias first Bio-CNG fuelling station," Chemical Engineering Transactions, vol. 18, pp. 617-622, 2009.

[56] Green Brick Eco Solutions, "Financial Analyses of Biogas to Bio CNG projects in India; Projections based case study analyses," 2016, http://gbes.in/. 
[57] A. Petersson and A. Wellinger, "Biogas upgrading technologies-developments and innovations," IEA Bioenergy, vol. 20, pp. 1-19, 2009.

[58] W. Papacz, "Biogas as Vehicle fuel," Journal of KONES Powertrain And Transport, vol. 18, pp. 403-410, 2011.

[59] A. V. Nawade, "Biogas to BioCNG/Biopower-Solutions for Waste-to-Green-Fuel Projects: An Experience Sharing," in Proceedings of the World Futur Energy Summit, Abu Dhabi, UAE, 2013.

[60] M. Alamgir and A. Ahsan, "Municipal solid waste and recovery potential: Bangladesh perspective, Iran," Journal of Environmental Health Science and Engineering, vol. 4, pp. 67-76, 2007.

[61] K. A. Bashar and A. Rahman, "Increase Use of CNG as Public Transport \& Reduce Emissions: A Comparative Study of the Benefits of CNG \& Automobiles Fuel: Present," Journal of Business Management, vol. 4, pp. 131-141, 2012.

[62] S. A. Iqbal, M. Iqbal, and A. F. M. Salauddin, "Present Scenario of Compressed Natural Gas (CNG) as a Vehicular fuel in Bangladesh," in Proceedings of the 2nd International Conference on Industrial Engineering and Engineering Management, pp. 222-228, 2011. 


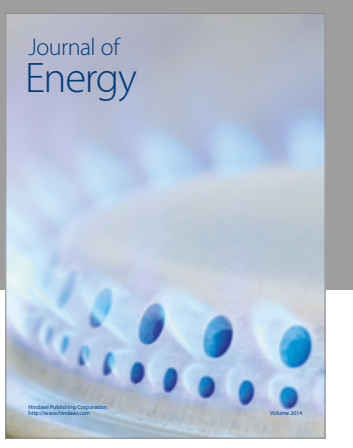

Journal of

Industrial Engineering
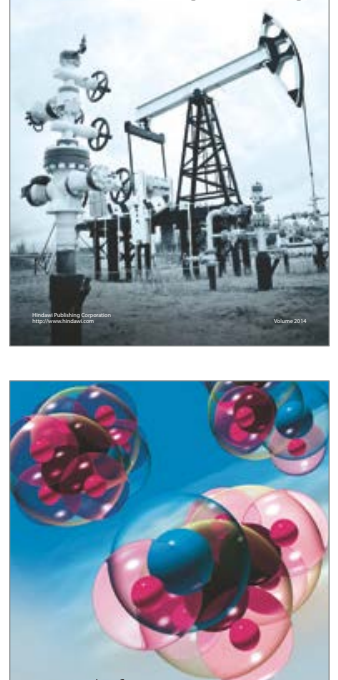

Fuels
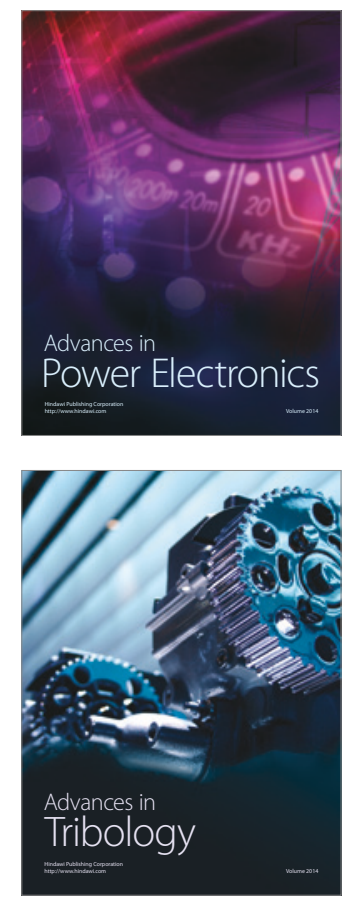
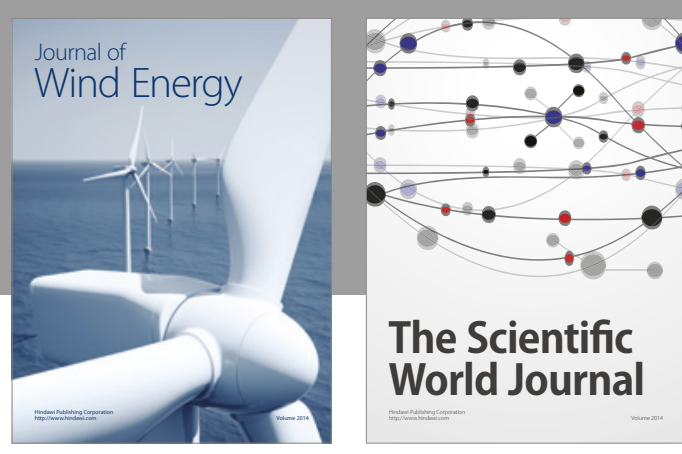

The Scientific World Journal
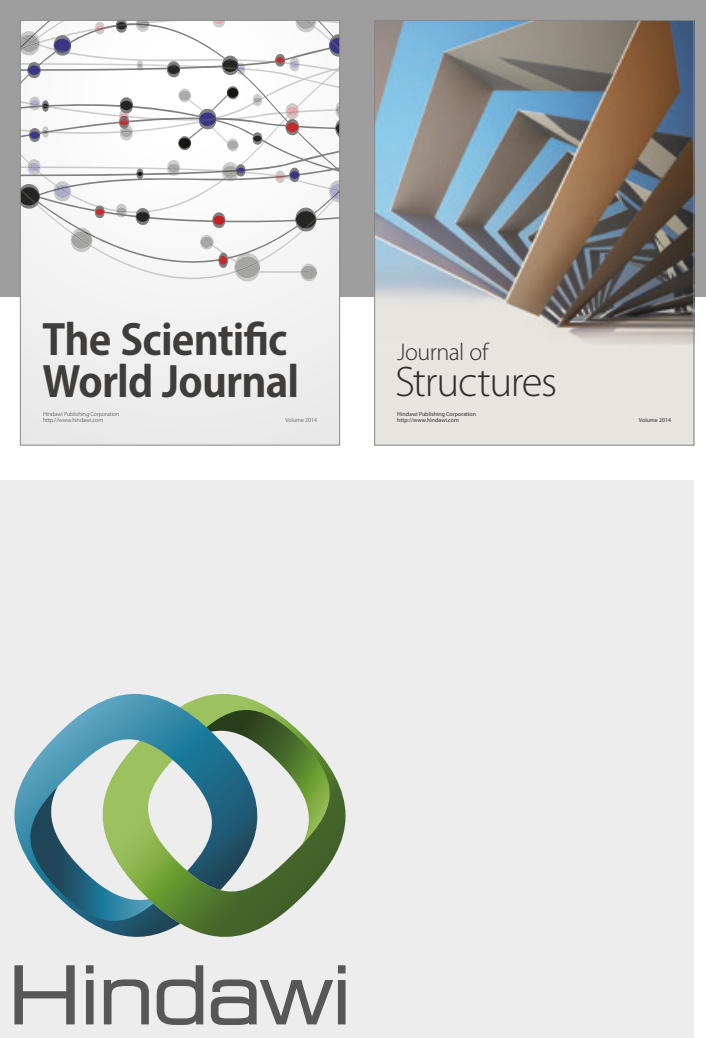

Submit your manuscripts at

https://www.hindawi.com
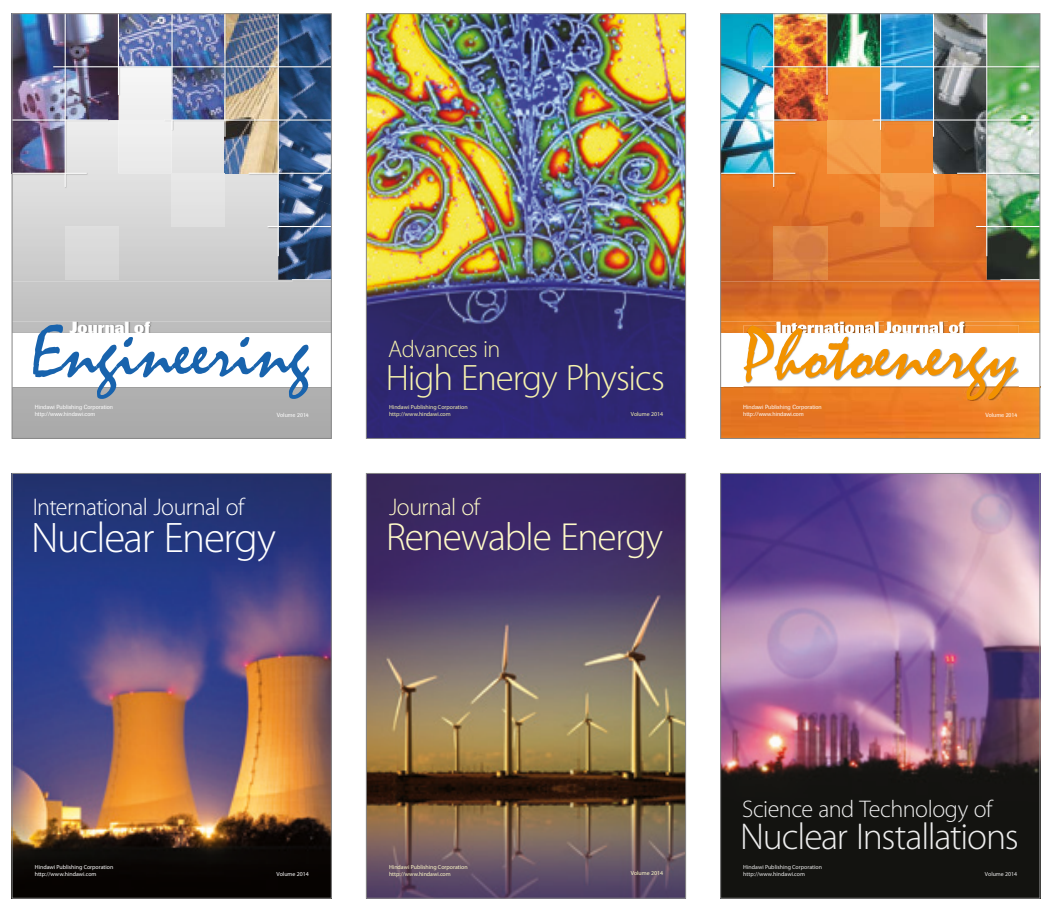

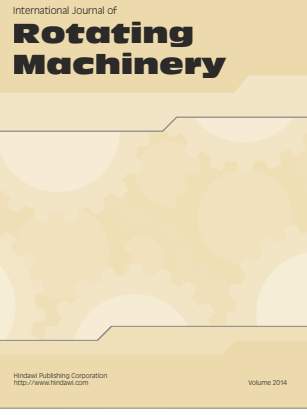

Journal of

Petroleum Engineering



Journal of
Solar Energy
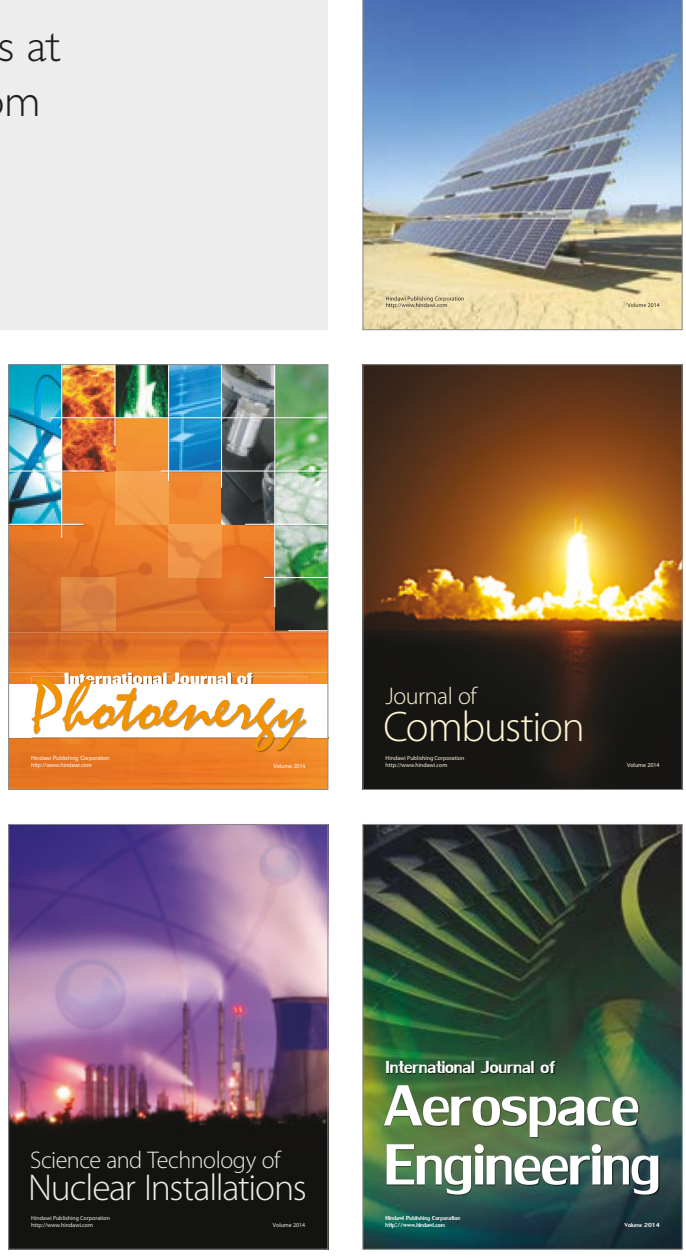